\title{
AN ION MICROPROBE U-Th-Pb STUDY OF ZIRCON XENOCRYSTS FROM THE LAHTOJOKI KIMBERLITE PIPE, EASTERN FINLAND
}

\author{
PETRI PELTONEN and IRMELI MÄNTTÄRI
}

PELTONEN, PETRI and MÄNTTÄRI, IRMELI 2001. An ion microprobe U$\mathrm{Th}-\mathrm{Pb}$ study of zircon xenocrysts from the Lahtojoki kimberlite pipe, eastern Finland. Bulletin of the Geological Society of Finland 73, Parts 1-2, 47-58.

Eleven relatively large (diameter 1-2 mm) zircon grains extracted from the Lahtojoki kimberlite pipe (Eastern Finland Kimberlite Province) have been analysed by the ion microprobe NORDSIM for their $\mathrm{U}$ - and $\mathrm{Pb}$ - isotopic composition. The ${ }^{207} \mathrm{~Pb} /{ }^{206} \mathrm{~Pb}$ ages fall into two concordant age groups: $2.7 \mathrm{Ga}$ and 1.8 Ga. Discordant ages between these two groups are believed to result from partial resetting of Archaean grains in the $1.8 \mathrm{Ga}$ thermal event. Since other dating methods imply that kimberlites emplaced c. $0.6 \mathrm{Ga}$ ago it is clear that the analysed zircons are xenocrysts inherited from older sources and do not provide the age of the kimberlite magmatism. Their unusual size and morphology, together with very low $\mathrm{U}$ - and $\mathrm{Pb}$-concentrations, suggest, however, that these zircon grains are not derived from typical Archaean gneisses. More likely, they originate from lower crustal mafic pegmatites and from hydrous coarse-grained veins within the uppermost lithospheric mantle. The predominance of $1.8 \mathrm{Ga}$ old xenocrystic grains, together with the recovery of mafic granulite xenoliths of similar age in the kimberlites (Hölttä et al. 2000), emphasises the importance of post-collisional lower crustal growth and reworking in central Fennoscandia.

Key words: kimberlite, pipes, zircon, xenoliths, crust, absolute age, U/Pb, Precambrian, Lahtojoki, Finland

Petri Peltonen and Irmeli Mänttäri: Geological Survey of Finland, P.O. Box 96, FIN-02151 Espoo, Finland 


\section{INTRODUCTION}

Zircon is an uncommon mineral in kimberlites. However, because of its physical properties it becomes concentrated with diamonds and is thus often available for study. The most characteristic features of the kimberlitic zircons are their very low $\mathrm{U}, \mathrm{Pb}$, Th and REE abundances, unusual large grain size, colour and trace element compositions. In addition, many kimberlitic zircons contain mantle minerals, such as olivine, Cr-diopside, $\mathrm{Cr}$-spinel, magnesian ilmenite, K-richterite and phlogopite, as inclusions (Kresten et al. 1975, Lyakhovich 1996, Belousova et al. 1999). Zircon has also been found as inclusions in diamonds (Meyer \& Svisero 1973) and in metasomatised mantle xenoliths (Konzett et al. 1998). These features imply that large zircon grains, i.e. megacrysts, in most cases are xenocrysts from the mantle where they most likely occur within coarse-grained metasomatic veins (e.g. Kinny et al. 1989).

In many cases (Davies 1976, 1977, Davies et al. 1980, Kinny et al. 1995) the U-Pb ages of these megacrysts are identical to the emplacement age of their host kimberlite determined by other methods, such as $\mathrm{Ar}-\mathrm{Ar}$ from micas or $\mathrm{U}-\mathrm{Pb}$ from perovskite. However, there is growing evidence that the megacryst series minerals are not cognate with the kimberlite magma. This suggests that zircon megacrysts crystallised in the mantle immediately before the extraction of the kimberlite melt or, alternatively, they may represent much older grains of any origin which effectively lost all their radiogenic lead while residing in the hot kimberlite magma.

In this paper we report single-grain U-Th- $\mathrm{Pb}$ isotope analyses of zircons recovered during testscale mining operations of the Lahtojoki kimberlite pipe and discuss their origin. The Lahtojoki kimberlite pipe is one of the approximately 20 kimberlitic bodies of the Eastern Finland Kimberlite Province, which c. $600 \mathrm{Ma}$ ago intruded the late Archaean basement complex and its early Proterozoic metasedimentary cover rocks close to the craton margin. This particular pipe is approximately $200 \mathrm{~m}$ x $100 \mathrm{~m}$ in size and suboval in shape. It is composed of macrocrystal heterolithic volcaniclastic kimberlite of the diatreme facies and mi- nor hypabyssal facies kimberlite. On the basis of petrography and mineralogical and isotopic data it is most akin to Group I kimberlites (Griffin et al. 1995). The petrology of Eastern Finland Kimberlite Province kimberlites and their mantle and lower crustal fragments has recently been extensively described by O`Brien and Tyni (1999), Peltonen et al. (1999), Peltonen (1999), Woodland and Peltonen (1999), Kukkonen and Peltonen (1999), Woodland et al. (1999) and Hölttä et al. (2000).

\section{ANALYTICAL TECHNIQUES}

Eleven zircon grains were extracted by handpicking from the nonmagnetic heavy mineral concentrate $\left(\mathrm{d}=2.9 \mathrm{~g} / \mathrm{cm}^{3} ; 0.5-10 \mathrm{~mm}\right.$ in diameter $)$ of the Lahtojoki kimberlite pipe. Zircons outside this grain-size range were not available for study, because the sieved fraction smaller than $0.5 \mathrm{~mm}$ was dumped in the process and coarse fractions larger than $10 \mathrm{~mm}$ were recycled to the crusher.

The selected zircons were mounted in epoxy, polished and coated with carbon for SEM and electron microprobe study, and with gold for SIMS analyses. Because of the different sizes of the zircon grains, a small platform was applied beneath small grains so that the final cutting would intersect all grains exactly through their cores. The U$\mathrm{Pb}$ analyses were run using the Nordic SIMS (NORDSIM) Cameca IMS 1270 at the Swedish Museum of Natural History, Stockholm. The spotdiameter for the $4 \mathrm{nA}$ primary $\mathrm{O}_{2}{ }^{-}$ion beam was ca. $30 \mu \mathrm{m}$, and oxygen flooding in the sample chamber was used to increase the production of $\mathrm{Pb}^{+}$ ions. Four counting blocks including total twelve cycles of the $\mathrm{Zr}, \mathrm{Pb}$, Th and $\mathrm{U}$ species were measured in each spot. The mass resolution was (M/ $\Delta \mathrm{M})$ of $5400(10 \%)$. The raw data were calibrated against a zircon standard (91500) and corrected for background (204.2) and age-related common lead (Stacey \& Kramers 1975). For a detailed description of the analytical procedure see Whitehouse et al. (1999).

BSE images were obtained and inclusion phases identified by JEOL Scanning Electron Microscope 
at the Geological Survey of Finland (GTK). Zircon compositions were determined by the wavelength dispersive technique using a Cameca Camebax SX50 instrument at GTK. Acceleration voltage of $25 \mathrm{kV}$ or $15 \mathrm{kV}$, probe current of $50 \mathrm{nA}$ or $25 \mathrm{nA}$, and beam diameter of $10 \mathrm{~mm}$ were applied. Standards included both natural and synthetic minerals, and data reduction was made using the PAP correction procedure supplied by Cameca.

\section{ZIRCON MORPHOLOGY AND SEM OBSERVATIONS}

Recovered zircons are 0.7-1.6 $\mathrm{mm}$ in length and thus much larger than normal crustal zircons. On the basis of their petrographic characteristics, they can be divided into groups A, B and C (Table 1). Group A consists of four (grain codes 01-04) equidimensional non-prismatic grains having length to width ratios close to $1: 1$. They are all non-zoned and enclose no inclusions (Fig. 1). The remaining grains are all prismatic with length to width ratios of c. 2:1. Prismatic grains can be either unzoned (Group B: 05, 07 and 11) or zoned (Group C: 06, 08, 09 and 10) and, with the exception of one grain, contain inclusions of feldspars, amphiboles and pyroxenes (Table 1). Group $\mathrm{C}$ grains frequently show typical igneous zoning or more diffuse banding in their back-scatter electron images. Grain number 10 consists of three distinct domains: the core domain being distinguished by its darker colour due to lower U-Th and $\mathrm{Pb}$ contents (Fig. 1). This domain is spatially associated with an area of intense fracturing and polymineralic rock fragment inclusions which consist of hornblende + plagioclase + Ba-feldspar, hornblende $+\mathrm{Fe}-\mathrm{Mn}-\mathrm{Mg}$ amphibole + plagioclase and hornblende $+\mathrm{Fe}-\mathrm{Mn}-\mathrm{Mg}$ amphibole. The brighter, intermediate, domain shows growth zoning typical of igneous zircons. Finally, the grain is mantled by an up to $50 \mathrm{~mm}$ thick rim of darker (low $\mathrm{U}-\mathrm{Th}-\mathrm{Pb}$ ) zircon. Grains 06,08 and 09 are also zoned but their zoning is not as well defined as that of grain 10. The core of the grain 06 is light brown and slighty turbid in transparent light being surrounded by a $40 \mathrm{~mm}$ thick U-Th-Pb enriched shell (Fig. 1). Most of the grain 06, however, consists of homogeneous, pink, transparent and unzoned zircon. Central parts of the grains 08 and 09 show ghost-like remnants of igneous zoning while large areas of the grain are composed of clear homogeneous zircon (Fig. 1).

\section{MINERAL CHEMISTRY}

The average $\mathrm{Zr} / \mathrm{Hf}$ value (as determined by WDS) of the Finnish kimberlitic zircons is 45.5. This value is within the range reported for zircon megacrysts in kimberlites (Kresten et al. 1975, Belousova et al. 1999). $\mathrm{Zr} / \mathrm{Hf}$ is not indicative of zircon

Table 1. Summary of the petrographic and mineral chemical characteristics of the 11 xenocrystic zircon grains recovered from the Lahtojoki pipe, Eastern Finland Kimberlite Province.

\begin{tabular}{|c|c|c|c|c|c|c|c|c|}
\hline Grain\# & size $(\mathrm{mm})$ & colour & & morphology & zoning & inclusions & $\mathrm{Zr} / \mathrm{Hf}$ & Group \\
\hline 02 & $1.5 \times 1.4$ & colourless & clear & equidimensional & - & - & 48.6 & A \\
\hline 03 & $1.2 \times 1.1$ & pink & gemmy & equidimensional & - & - & 52.9 & A \\
\hline 04 & $1.1 \times 1.0$ & pink & clear & equidimensional & - & - & 34.9 & A \\
\hline 05 & $1.2 \times 0.8$ & $\begin{array}{l}\text { light brown - } \\
\text { pink }\end{array}$ & turbid - clear & prismatic & - & labradorite, hypersthene & 64.8 & $\mathrm{~B}$ \\
\hline 11 & $0.7 \times 0.3$ & colourless & clear & prismatic & - & potassium feldspar, talc & 41.7 & $\mathrm{~B}$ \\
\hline 06 & $1.1 \times 0.5$ & $\begin{array}{l}\text { light brown - } \\
\text { pink }\end{array}$ & turbid - clear & prismatic & yes & $\begin{array}{l}\text { aegerine-augite, hypersthe- } \\
\text { ne, hornblende, actinolite }\end{array}$ & 47.6 & $\mathrm{C}$ \\
\hline 08 & $1.1 \times 0.6$ & pink & clear & prismatic & yes & - & 39.4 & $\mathrm{C}$ \\
\hline 09 & $1.0 \times 0.6$ & pink & clear & prismatic & yes & hornblende, hypersthene & 43.3 & $\mathrm{C}$ \\
\hline 10 & $1.2 \times 0.7$ & deep red & turbid & prismatic & yes & $\begin{array}{l}\text { hornblende, Fe-Mg } \\
\text { amphibole, Ba-feldspar, } \\
\text { andesine }\end{array}$ & 37.5 & $\mathrm{C}$ \\
\hline
\end{tabular}





Fig. 1. SEM images of selected zircon grains recovered from the Lahtojoki kimberlite pipe with points of NORDSIM analyses and corresponding ages $(\mathrm{Ma})$. All the grains that show intragrain heterogeneity with respect to chemical composition or ages, as well as representative examples of equidimensional Group A grains (03, 04) are shown. 


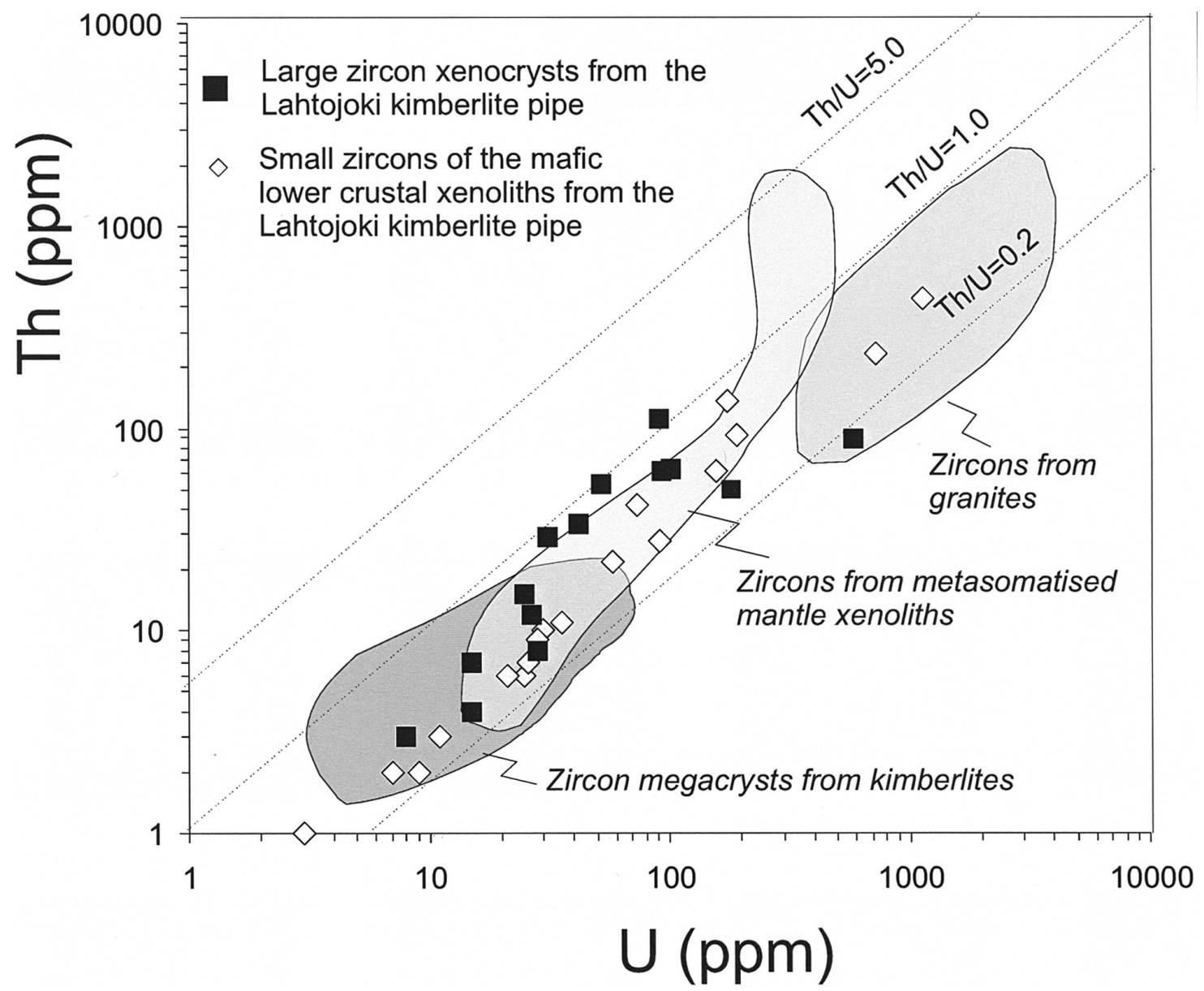

Fig. 2. U-Th relationship of the xenocrystic zircons from the Lahtojoki pipe (data from Table 2) and zircons extracted from two lower crustal xenoliths recovered from the same pipe (data from Hölttä et al. 2000). Fields for zircon megacrysts from kimberlites (Ahrens et al. 1967, Krasnobayev 1980, Kinny et al. 1989, Belousova 1999), metasomatised mantle xenoliths (Konzett et al. 1998) and granitic rocks (Ahrens et al. 1967) are indicated for comparison.

origin because zircon suites from felsic and mafic igneous rocks may have equal values (Heaman et al. 1990). The total ranges of $U$ and Th within the analysed zircons are 8-588 ppm and 3-128 ppm, respectively. Approximately half of the grains - including both equidimensional and prismatic - are characterised by anomalously low U $(<30 \mathrm{ppm})$ and Th $(<10 \mathrm{ppm})$ abundances similar to those in zircon megacrysts from South African and Yakutian kimberlites. Thorium and $\mathrm{U}$ abundances and $\mathrm{Th} / \mathrm{U}$ alone are not, however, adequate parametes to determine zircon origin. This is because zircons from metasomatised mantle rocks may have crustal-like U-Th systematics, and zircons from mafic lower crustal granulites may be identical with zircon megacrysts of mantle origin (Fig. 2).

\section{U-Pb DATING RESULTS}

The analysed zircon grains yielded a large range of ages which, however, tend to correlate with the general habit of the grains (Table 2, Fig. 3). The most crustal-like grain, i.e. the dark-brown, prismatic and strongly growth-zoned grain number 10, yielded the oldest ages. The $\mathrm{U}$ - and $\mathrm{Pb}$-rich intermediate (10A) and outer zones (10B) record Ar- 




Fig. 3. U-Pb concordia diagram for the zircon xenocrysts from the Lahtojoki kimberlite pipe. Inset shows the 1.8 Ga group analyses in more detail.

chaean ${ }^{207} \mathrm{~Pb} / 206 \mathrm{~Pb}$ ages, while the core of the same grain yields a younger age of c. $2.4 \mathrm{Ga}$. Grains 06 and 08 also yield significantly older ages than most of the grains. These two grains are similarly zoned, but their zoning is less prominent compared to grain 10 giving an impression of partial destruction of an original more profound growthzoning. They yield a broad range of somewhat discordant ages between c. 2.1 and $2.6 \mathrm{Ga}$. The youngest ages in both grains are recorded by their $\mathrm{U}$ - and $\mathrm{Pb}$-depleted marginal zones.

Most of the grains record ${ }^{207} \mathrm{~Pb} /{ }^{206} \mathrm{~Pb}$ ages close to $1.8 \mathrm{Ga}$. The weighted average of concordant zircons is $1789 \pm 24 \mathrm{Ma}$ indicating a major thermal episode at that time (Fig. 4). Importantly, this young zircon population includes all equidimensional inclusion-free grains of Group A, all prismatic unzoned grains of Group B and one pris- matic zoned grain (09) with ghost-like remnants of growth-zoning.

\section{DISCUSSION}

\section{Age of the kimberlites}

The first attempts to date the eastern Finland kimberlites were $\mathrm{K}-\mathrm{Ar}$ determinations of two whole rock samples from pipes number 1 and 2 which gave ages of $430 \mathrm{Ma}$ and $560 \mathrm{Ma}$, respectively (Tyni 1997). However, because pure mineral separates were not analysed these ages were regarded only as rough estimate of the true age. Peltonen et al. (1999) provided an independent estimate of the emplacement age: garnet and clinopyroxene separated from four garnet-peridotite xenoliths from the Lahtojoki pipe yielded two-mineral Sm- 


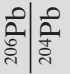

胥

五



2

己

$\stackrel{0}{\circ}$ o

$\frac{8}{\simeq}$

$b_{+1}^{0}$ o

㝕|

io

0
0
0
0
0
0
0
0

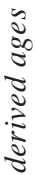

जิ|

o bo

है। है

o

\)

o

है।

o

से| हि

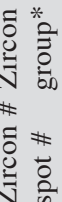

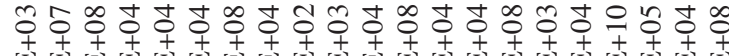

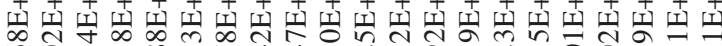
家两

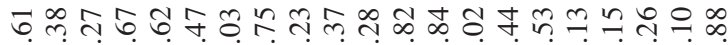
०00 0 0 0 0

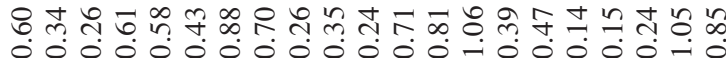





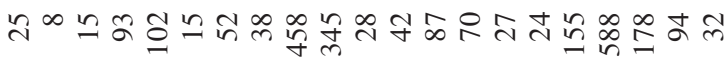

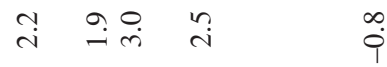



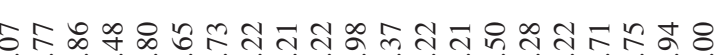






केิ -

ปิ Ұ

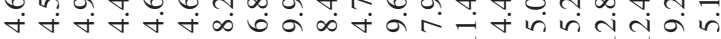

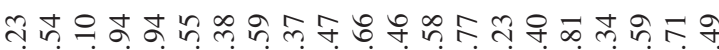

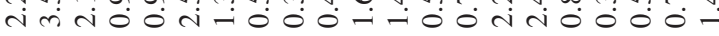

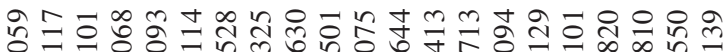

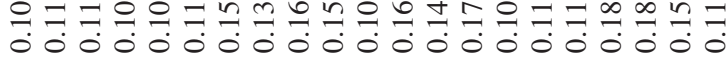













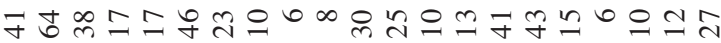

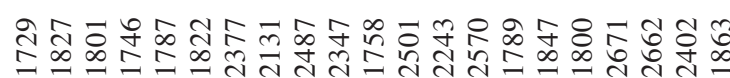
$\varangle \varangle \varangle \varangle \varangle \oplus \cup \cup \cup \cup n \cup \cup \cup \cup \cup \cup \cup \cup \cup n$

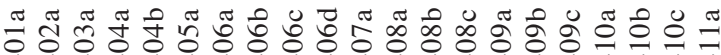

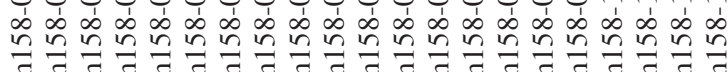

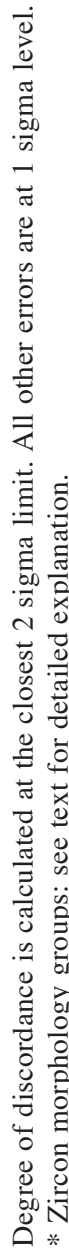


$\mathrm{Nd}$ isochron ages between $525 \pm 10$ and $607 \pm 20$ Ma. Because chemical composition of garnet and clinopyroxene suggests that they were in or close to chemical equilibrium with respect to REE when the xenoliths were detached from the lithospheric mantle, the youngest isochron age of $525 \mathrm{Ma}$ provides a close estimate for the emplacement of the kimberlite. The most appropriate method to date kimberlite magmatism is, however, by U-Pb method on perovskite, that is a mineral which crystallises from the kimberlite melt itself. Such a work is in progress and the preliminary results indicate that the Finnish kimberlites were emplaced c. 600 Ma ago (Hugh O' Brien, personal communication 2000).

In the light of the above review, it is evident that the ${ }^{207} \mathrm{~Pb} / 206 \mathrm{~Pb}$ ages recorded by the zircon crystals recovered from the Lahtojoki kimberlite pipe are much older than the emplacement age of the eastern Finland kimberlites. Clearly, the studied zircon grains have not crystallised from their host kimberlite melt but occur as exotic xenocrysts derived from older sources.

\section{Origin of the zircons in the Lahtojoki pipe}

On the basis of their morphology, zoning and inclusion suite, the studied grains were divided into

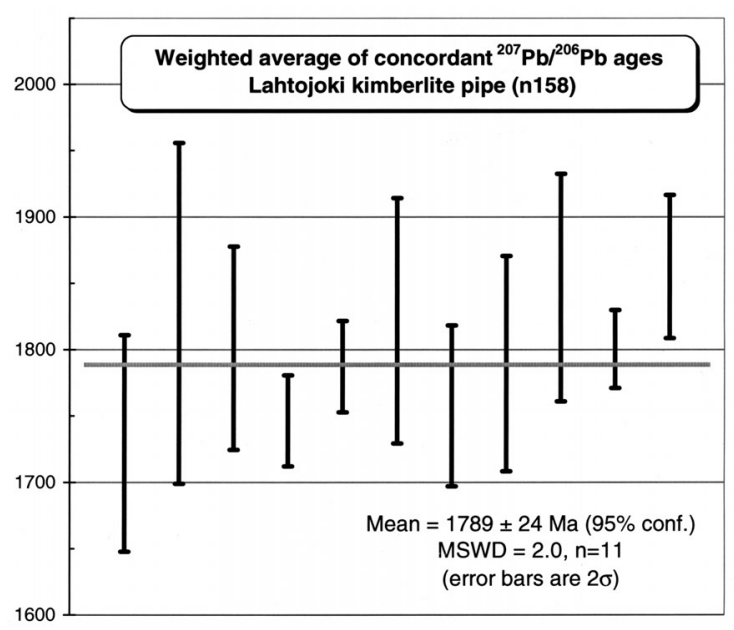

Fig. 4. Concordant ${ }^{207} \mathrm{~Pb} / 206 \mathrm{~Pb}$ ages of the $1.8 \mathrm{Ga}$ group zircon grains from the Lahtojoki kimberlite pipe with $2 \sigma$ error bars. three subgroups A, B and C (Table 1). Group C consists of prismatic grains which exhibit zoning on the BSE images: they record a variety of ages between 1790-2670 Ma and exhibit considerable intragrain heterogeneity. Results from the grain 10 are particularly important: low $\mathrm{U}$ and $\mathrm{Pb}$ contents of the core, together with its highly fractured appearance and intimate association with large silicate inclusions, suggest that the younger age of the core results from $\mathrm{U}$ - and $\mathrm{Pb}$-loss (accompanied by Th-gain) during alteration. Grains 06 and 08 also show considerable intragrain heterogeneity of ages. Because the younging of the ages is accompanied by weakening of the zoning and by the appearance of large domains of non-zoned zircon in these grains, we believe that the discordant ages between the $2.7 \mathrm{Ga}$ and $1.8 \mathrm{Ga}$ age groups do not have any geological significance but represent older grains, probably Archaean, which have experienced partial lead-loss during a younger episode. Grain 09, in turn, is similar to the old Group C zircons in showing ghost-like remnants of igneous zoning but yields only young ages close to 1.8 Ga within all domains. These features, together with similar inclusions as in the old zircons, suggest that grain 09 represents a fairly advanced stage of resetting of old grains. The inclusion suite of Group C zircons, dominated by pyroxenes and amphiboles (Table 1), differs from inclusions identified in zircon megacrysts of kimberlites and zircons of metasomatised mantle xenoliths which host primary and metasomatic mantle minerals such as olivine, $\mathrm{Cr}$-diopside, $\mathrm{Cr}$-spinel, magnesian ilmenite, K-richterite, rutile, apatite, phlogopite, $\mathrm{Ni}-\mathrm{Fe}$ sulfides and diamond (Kresten et al. 1975, Lyakhovich 1996, Konzett et al. 1998). Most likely, all Group C zircons were derived from deepseated Archaean rocks which have experienced variable $\mathrm{U}-\mathrm{Pb}$ disturbance and recrystallisation processes in a thermal event at c. $1.8 \mathrm{Ga}$. The high $\mathrm{U}$ and Th contents and plagioclase and Ba-feldspar bearing inclusion suite of grain 10 suggest granitic protolith for that grain. The remaining Group C zircons contain only pyroxene and amphibole inclusions and are believed to originate either from mafic lower crustal pegmatites or, more likely, from hydrous pyroxenitic mantle 
dykes similar to those common in orogenic lherzolite massifs (Bodinier et al. 1987, Peltonen et al. 1998) and upper mantle xenoliths erupted with alkali basalts (e.g. Wilshire et al. 1980).

Group B includes grains 05, 07 and 11 (Table 1). These grains resemble those of Group $C$ in being prismatic and in containing some silicate inclusions. However, they differ from the Group C grains because they do not show any kind of intragrain heterogeneity with respect to chemical composition or age. Two alternative origins can be postulated for the Group B grains. First, they may represent new zircons that crystallised from magmas in the $1.8 \mathrm{Ga}$ event or, alternatively, old grains similar to those of Group $\mathrm{C}$ but which have been completely reset/recrystallised by protracted residence at a high ambient (lower crustal?) temperature. Their inclusion suite consists of both plagioclase and potassium feldspar together with orthopyroxene (Table 1), a feature which suggests a pyroxene granite protolith for the Group B grains.

Group A grains are distinct from all other grains (Table 1). They are non-prismatic, equidimensional and inclusion-free grains which record ages close to $1.8 \mathrm{Ga}$. Because of their morphology and absence of inclusions we believe that they crystallised in an environment different from that of Group B and Group C zircons. Since there is no clear process by which Group B or C zircons could become inclusion-free during recrystallisation, Group A grains most likely represent new grains crystallised from magmas c. $1.8 \mathrm{Ga}$ ago. Their low $\mathrm{U}$ and $\mathrm{Pb}$ abundances and their large grain size, which is more than a magnitude larger than that of zircons in lower crustal xenoliths (Hölttä et al. 2000), suggest that they most likely were derived from mafic to ultramafic lower crustal pegmatites or coarse-grained mantle veins.

\section{Implications}

Although we failed to determine the age of the kimberlites by U-Pb analyses of zircons the study turns out to have several implications. First, several of the grains have been reset in the $1.8 \mathrm{Ga}$ event but show no evidence for even minor disturbance caused by their residence in kimberlite melt during eruption $600 \mathrm{Ma}$ ago. We believe that this is due to the very low $\mathrm{U}$ concentrations, slow diffusion of $\mathrm{Pb}, \mathrm{U}$ and $\mathrm{Th}$ in zircon, and the high closure temperature (of the order of $1000^{\circ} \mathrm{C}$ ) for such large $(1000 \mu \mathrm{m})$ grains at all relevant cooling rates (Lee et al. 1997) and due to the very short residence-time of the grains in their host kimberlite. A similar conclusion was reached e.g. by Kinny et al. (1989) who reported the presence of Archaean zircon grains in the Permian Jwaneng DK2 kimberlite (Botswana). Whether these Archaean Jwaneng grains were indeed derived from pegmatoidal veins in the uppermost lithospheric mantle, as argued by Kinny et al. (1989), or represent xenocrysts from crustal sources, as their trace element patterns would suggest (Belousova et al. 1999), they do indicate that interaction of zircon with kimberlite melt is incapable to reset zircon.

The predominance of c. $1.8 \mathrm{Ga}$ old concordant zircons (Table 2, Fig. 4) in the Lahtojoki pipe is intriguing. This age clearly postdates the major phases of the Svecofennian orogeny, and rocks of this age do not have surface expression close to the kimberlites. However, similar ages close to 1.8 Ga were obtained by Hölttä et al. (2000), who extracted zircons from two lower crustal mafic granulite xenoliths recovered from the same kimberlite pipe. One of their samples (L-94) gave concordant ages close to $1.8 \mathrm{Ga}$, while the other sample $(7 \mathrm{HH})$ yielded a heterogeneous zircon population with the youngest ages close to $1.8 \mathrm{Ga}$. The fact that both xenocrystic large zircons from kimberlites and small zircons extracted from mafic lower crustal xenoliths record similar post-collisional ages implies that such a thermal event has been important in the lower crustal/uppermost mantle environment. Probably, a substantial part of the present lower crust in eastern Finland is composed of mafic granulites of magmatic origin (Hölttä et al. 2000). The intrusion of voluminous mafic melts at $1.8 \mathrm{Ga}$ into the pre-existing lower crust must have had a major thermal imprint resulting in local production of felsic magmas.

Elsewhere in Finland several post-collisional granitoids falling within this age group are indeed known. These include the extensive Central-Lapland granitoid complex (Lauerma 1982) and Nat- 
tanen (Patchett et al. 1981) and Hetta (Meriläinen 1976) granites in northern Finland. Interestingly, this is also the approximate age of the epigenetic Au-mineralisations in northern Finland as recorded by monazite from the Saattopora Au-deposit and by the $\mathrm{Pb}-\mathrm{Pb}$ ages of several other Au-occurrences over a wide area (Mänttäri 1995). Several felsic intrusions in southern and central Finland, such as Puruvesi (Nykänen 1983), Ruokolahti (Nykänen 1988), Mikkeli (Patchett \& Kouvo 1986), Takiankangas (Kärki 1995), Anttola (Korsman 1984), Parkkila (Simonen 1982) and Hanko (Huhma 1986), also belong to this age group. Furthermore, Eklund et al. (1998) have outlined a belt consisting of at least fourteen $1.8 \mathrm{Ga}$ old post-collisional shoshonitic intrusions in southern Finland and Russian Karelia. These intrusions range from ultramafic, calc-alkaline potassium lamprophyres to peraluminous granites and are believed to have been derived from a lithospheric mantle source affected by carbonate metasomatism. Eklund et al. (1998) concluded that the regional distribution of such intrusions may indicate that large volumes of $1.8 \mathrm{Ga}$ juvenile material resides in unexposed parts of the crust. Direct evidence for the presence of lower crust of this age is now available from eastern Finland (this study, Hölttä et al. 2000) and from the Belomorian Mobile Belt in Kola Peninsula (Downes et al. in prep).

\section{CONCLUSIONS}

Large zircon grains recovered from the Lahtojoki pipe are not cogenetic with their kimberlite host but occur as xenocrysts derived from older source rocks. Prismatic grains are derived from Archaean lower crustal or uppermost mantle sources. In most cases these grains bear evidence for partial $\mathrm{U}$ - and $\mathrm{Pb}$-loss due to the post-collisional $1.8 \mathrm{Ga}$ thermal event. Equidimensional grains, in turn, originate from $1.8 \mathrm{Ga}$ old lower crustal pegmatites or hydrous veins in the uppermost mantle. This work, together with recent data from mafic lower crustal granulite xenoliths (Hölttä et al. 2000), suggests that the $1.8 \mathrm{Ga}$ old post-collisional event was a major episode of crustal growth and rework- ing in central Fennoscandian Shield.

ACKNOWLEDGEMENTS. Matti Tyni is thanked for providing the zircons for study and the NORDSIM staff at Stockholm for keeping the wheels running. This work was supported by grant 40553 from the Academy of Finland. We thank W.L. Griffin, E.A. Belousova, O. Eklund and editor $Y$. Kähkönen for constructive comments that led to the improvement of the manuscript. This is NORDSIM contribution number 48.

\section{REFERENCES}

Ahrens, L.H., Cherry, R.D. \& Erlank, A.J. 1967. Observations on the Th- $U$ relationship in zircons from granitic rocks and kimberlites. Geochimica et Cosmochimica Acta 31, 2379-2387.

Belousova, E.A., Griffin, W.L. \& O'Reilly, S.Y. 1999. Cathodoluminescense and geochemical properties of kimberlitic and lamproitic zircons. In: Gurney et al. (eds.) Proceedings of the $7^{\text {th }}$ International Kimberlite Conference, Cape Town, South Africa, Vol. 1, 23-29.

Bodinier, J-L., Fabriès, J., Lorand, J-P., Dostal, J. \& Dupuy, C. 1987. Geochemistry of amphibole pyroxenite veins from the Lhertz and Freychinède ultramafic bodies Arièga, French Pyrenees. Bulletin de Minéralogie 110, 345-358.

Davies, G.L., Krogh, T.E. \& Erlank, A.J. 1976. The ages of zircon from kimberlites from South Africa. Carnegie Institution of Washington Year Book 75, 821-824.

Davies, G.L. 1977. The ages and uranium contents of zircons from kimberlites and associated rocks. Carnegie Institution of Washington Year Book 76, 631-635.

Davies, G.L., Sobolev, N.V. \& Khar'kiv, A.D. 1980. New data on the age of Yakutian kimberlites obtained by the uranium-lead method on zircons. Doklady Akademii Nauk SSSR 254, 175-179.

Eklund, O., Konopelko, D., Rutanen, H., Frödjö, S. \& Shebanov, A.D. 1998. 1.8 Ga Svecofennian post-collisional shoshonitic magmatism in the Fennoscandian shield. Lithos 45, 87-108.

Griffin, B.J., Rissanen, J., Pooley, G.D., Lee, D.C., MacDonald, I. \& Kinny, P.D. 1995. A new diamondiferous eclogite-bearing kimberlitic occurrence from Finland. In: Sixth International Kimberlite Conference, Novosibirsk, Russia, Extended Abstracts, 198-200.

Heaman, L.M., Bowins, R. \& Crocket, J. 1990. The chemical composition of igneous zircon suites: Implications for geochemical tracer studies. Geochimica et Cosmochimica Acta 54, 1597-1607.

Hölttä, P., Huhma, H., Mänttäri, I., Peltonen, P. \& Juhanoja, J. 2000. Petrology and geochemistry of mafic granulite xenoliths from the Lahtojoki kimberlite pipe, east- 
ern Finland. Lithos 51, 109-133.

Huhma, H. 1986. Sm-Nd, U-Pb and $\mathrm{Pb}-\mathrm{Pb}$ isotopic evidence for the origin of the Early Proterozoic Svecokarelian crust in Finland. Geological Survey of Finland, Bulletin $337.48 \mathrm{p}$

Kärki, A. 1995. Palaeoproterozoic shear tectonics in the central Fennoscandian Shield, Finland. Res Terrae, Ser. A 10.98 p.

Kinny, P.D., Compston, W., Bristow, J.W. \& Williams, I.S. 1989. Archaean mantle xenocrysts in a Permian kimberlite: two generations of kimberlitic zircon in Jwaneng DK2, southern Botswana. In: Ross, J. (ed.) Kimberlites and related rocks. Geological Society of Australia, Special Publication 14, 833-842.

Kinny, P.D., Griffin, B.J. \& Brakhfogel, F.F. 1995. Shrimp U-Pb ages of perovskite and zircon from Yakutian Kimberlites. In: Sixth International Kimberlite Conference, Novosibirsk, Russia, Extended Abstracts, 275-276.

Konzett, J., Armstrong, R.A., Sweeney, R.J. \& Compston, W. 1998. The timing of MARID metasomatism in the Kaapvaal mantle: An ion probe study of zircons from the MARID xenoliths. Earth and Planetary Science Letters 160, 133-145.

Korsman, K., Hölttä, P., Hautala, T. \& Wasenius, P. 1984. Metamorphism as an indicator of evolution and structure of the crust in Eastern Finland. Geological Survey of Finland, Bulletin 328. 40 p.

Krasnobayev, A.A. 1979. Mineralogical-geochemical features of zircons from kimberlites and problems of their origin. International Geology Review 22, 1199-1209.

Kresten, P., Fels, P. \& Berggren, G. 1975. Kimberlitic zircons - a possible aid in prospecting for kimberlites. Mineralium Deposita 10, 47-56.

Kukkonen, I. \& Peltonen, P. 1999. Xenolith-controlled geotherm for the central Fennoscandian Shield - implications for the lithosphere-asthenosphere relation. Tectonophysics 304, 301-315

Lauerma, R. 1982. On the ages of some granitoid and schist complexes in northern Finland. Bulletin of the Geological Society of Finland 54, 85-100.

Lee, J.K.W., Williams, I.S. \& Ellis, D.J. 1997. Pb, U and Th diffusion in natural zircons. Nature 390, 159-161.

Lyakhovich, V.V. 1996. Zircons in diamond-bearing rocks. Transactions (Doklady) of the USSR Academy of Sciences, Earth Science Section 347, 179-199.

Mänttäri, I. 1995. Lead isotope characteristics of epigenetic gold mineralization in the Palaeoproterozoic Lapland greenstone belt, northern Finland. Geological Survey of Finland, Bulletin 381.70 p.

Meriläinen, K. 1976. The granulite complex and adjacent rocks in Lapland, northern Finland. Geological Survey of Finland, Bulletin 281. 129 p.

Meyer, H.O.A. \& Svisero, D.P. 1973. Mineral inclusions in Brasilian diamonds. Physics and Chemistry of the Earth 9, 785-795.

Nykänen, O. 1983. Punkaharjun ja Parikkalan kartta-alueiden kallioperä. Summary: Pre-Quaternary rocks of the Punkaharju and Parikkala map-sheet areas. Geological map of Finland 1: 100 000, Explanation to the maps of Pre-Quaternary rocks, Sheets 4124+4142, 4123+4114. Geological Survey of Finland. 81 p.

Nykänen, O. 1988. Virmutjoen kartta-alueen kallioperä. Summary: Pre-Quaternary rocks of the Virmutjoki mapsheet area. Geological map of Finland 1 : 100 000, Explanation to the map of Pre-Quaternary rocks, Sheet 4121. Geological Survey of Finland. 64 p.

O’Brien H. \& Tyni M. 1999. Mineralogy and geochemistry of kimberlites and related rocks from Finland. In: Gurney et al. (eds.) Proceedings of the $7^{\text {th }}$ International Kimberlite Conference, Cape Town, South Africa, Vol. 2, 625-636.

Patchett, P.J., Kouvo, O., Hedge, C.E. \& Tatsumoto, M. 1981. Evolution of continental crust and mantle heterogeneity: evidence from Hf isotopes. Contributions to Mineralogy and Petrology 78, 279-297.

Patchett, J. \& Kouvo, O. 1986. Origin of continental crust of 1.9-1.7 Ga age: $\mathrm{Nd}$ isotopes and $\mathrm{U}-\mathrm{Pb}$ zircon ages in the Svecokarelian terrain of south Finland. Contributions to Mineralogy and Petrology 92, 1-12.

Peltonen, P., Kontinen, A. \& Huhma, H. 1998. Petrogenesis of the mantle sequence of the Jormua ophiolite, Finland: melt migration in the upper mantle during Palaeoproterozoic continental break-up. Journal of Petrology 39, 297-329.

Peltonen, P. 1999. Silicification of garnet peridotite xenoliths from the Lahtojoki kimberlite pipe, Finland. In: Gurney et al. (eds.) Proceedings of the $7^{\text {th }}$ International Kimberlite Conference, Cape Town, South Africa, Vol. 2, 659-663.

Peltonen, P., Huhma, H., Tyni, M. \& Shimizu, N. 1999. Garnet-peridotite xenoliths from kimberlites of Finland: nature of the continental mantle at Archaean craton Proterozoic mobile belt transition. In: Gurney et al. (eds.) Proceedings of the $7^{\text {th }}$ International Kimberlite Conference, Cape Town, South Africa, Vol. 2, 664-676.

Simonen, A. 1982. Mäntyharjun ja Mikkelin kartta-alueiden kallioperä. Summary: Pre-Quaternary rocks of the Mäntyharju and Mikkeli map-sheet areas. Geological map of Finland 1 : 100 000, Explanation to the maps of Pre-Quaternary rocks, Sheets 3123, 4142. Geological Survey of Finland. 36 p.

Stacey, J.S. \& Kramers, J.D. 1975. Approximation of the terrestrial lead isotope evolution by a two-stage model. Earth and Planetary Science Letters 26, 207-221.

Tyni, M. 1997. Diamond prospecting in Finland - a review. In: Papunen, H. (ed.) Mineral Deposits: Research and Exploration, Where do They Meet? Proceedings of the $4^{\text {th }}$ biennal SGA Meeting, 789-791.

Whitehouse, M.J., Kamber, B. \& Moorbath, S. 1999. Age significance of $\mathrm{U}-\mathrm{Th}-\mathrm{Pb}$ zircon data from early Archaean rocks of west Greenland - a reassessment based on combined ion-microprobe and imaging studies. Chemical Geology 160, 201-224.

Wilshire, H.G., Pike, J.E.N., Meyer, C.E. \& Schwarzman, E.C. 1980. Amphibole-rich veins in lherzolite xenoliths, Dish Hill and Deadman Lake, California. American Journal of Science 280-A, 576-593. 
Woodland, A.B. \& Peltonen, P. 1999. Ferric/ferrous iron contents of garnet and clinopyroxene and calculated oxygen fugacities of peridotite xenoliths from the Eastern Finland Kimberlite Province. In: Gurney et al. (eds.) Proceedings of the $7^{\text {th }}$ International Kimberlite Conference, Cape Town, South Africa, Vol. 2, 904-911.
Woodland, A.B., Seitz, H.-M. \& Peltonen, P. 1999. Light and transition element compositions of garnet and clinopyroxene from eclogite xenoliths from the Eastern Finland Kimberlite Province. In: EUG 10, European Union of Geosciences, 28.3.-1.4. 1999, Strasbourg (France), Abstract Volume, p. 821. 